National Agricultural Advisory Service in the Yorkshire and Lancashire Province. Mr. Williams, who is forty-three, graduated in agricultural botany from the University College of North Wales, Bangor, in 1941. Before his university studies he had considerable practical experience, including eight years on his father's mixed farm in the Conway Valley and a year as manager of a large dairy farm. He joined the Ministry of Agriculture and Fisheries in 1942, becoming two years later a technical development officer for the county of Buckinghamshire. Mr. Williams has taken particular interest in the development of herbage seed growing in Buckinghamshire and the East Midlands, and has been a member of the Management Committee and vice-chairman of the Certifying Committee of the Lincolnshire Seed Growers' Association. He has also been a member of various young farmers' clubs advisory committees and has lectured frequently to farmers' clubs and societies. He was one of the official United Kingdom delegates to both the Fifth International Grassland Congress held in Holland in 1949 and the Sixth Congress held in the United States in 1952, and at the latter he afterwards toured extensively in the Middle West, visiting farms and research stations.

\section{Royal Aeronautical Society:}

Mr. E. T. Jones, C.B., O.B.E.

Mr. E. T. Jones, principal director of scientific research (air), Ministry of Supply, has been elected president of the Royal Aeronautical Society for the year 1956-57 and will take office at the annual general meeting of the society, to be held on May 10, 1956 . Mr. Jones, who is fifty-eight, was a pilot and flying instructor in the R.F.C./R.A.F. during 1915-19, and then graduated from the University of Liverpool. During $1923-30$ he was with the Aerodynamics Department, Royal Aircraft Establishment, and for eight years was with the Marine Aircraft Experimental Establishment, Felixstowe. During the Second World War he was chief superintendent of the Aeroplane and Armament Experimental Establishment, Boscombe Down; in 1947 he was appointed director of instrument research and development at the Ministry of Supply, and was promoted to his present position at the Ministry in 1949. Mr. Jones was created an O.B.E. in 1942 and C.B. in 1953.

\section{American Academy of Arts and Sciences: Award of Francis Amory Prizes}

Francis Amory prizes of 3,500 dollars each, for the invention or discovery of measures for the relief or cure of diseases affecting the genito-urinary system, have been awarded by the American Acaderny of Arts and Sciences as follows: Frederic E. B. Foley, Lowry Medical Arts Building, St. Paul, Minnesota, for outstanding inventive and surgical genius in the treatment of those afflicted with urological disease ; Choh Hao Li, University of California, Berkeley, California, for his work on the relation of the anterior pituitary hormones to the maintenance and functioning of the human reproductive organs; T. R. R. Mann, Molteno Institute, University of Cambridge, for his basic contributions to the biochemistry of reproductive functions providing basic data stimulating research and clinical progress; Terence J. Millin, Queen's Gate Clinic, London, for his contribution to surgery ; Warren $O$. Nelson, College of Medicine, State University of Iowa, for his studies of the structural relationships of the male sex organs and of the factors that determine the functional activities of their components ; Frederick J. Wallace, American Cystoscope Makers, Inc., New York, for his co-operation with the urological profession in developing diagnostic and therapeutic instruments which have contributed materially to the technical advances in this specialty; Lawson Wilkins, Johns Hopkins University, Baltimore, Maryland, in recognition of his contributions to fundamental knowledge of the growth and development of secondary sex character. istics in man and his application of the adrenal cortical hormone to their management and treat. ment.

\section{New Headquarters for the Institute of Biology}

THE Institute of Biology, having spent the first five years of its existence in rooms at Tavistock House, has moved to new premises at 41 Queen's Gate, London, S.W.7 (Tel. : Western 2229). The new rooms are in the house of the Royal Entomological Society, and the meeting room of this Society is to be made available to the Institute of Biology for certain of its meetings. The removal marks a stage in the development of the Institute, which has now achieved a membership of twelve hundred full members, seventy probationer members and three hundred student members. The new headquarters will provide facilities not previously available to members. In particular, a members' room has been provided in which members will be able to meet friends, conduct interviews and hold small discussion groups. A telephone and ample space for writing and reading will be provided. A selection of works of reference will be available, and there will be a frequently changed display of recent books on biological subjects, maintained by a leading scientific bookseller. While it is not proposed to attempt to build up a comprehensive library because of the existence of the neighbouring libraries dealing with various branches of biology, the Institute may establish a collection of books on the broader aspects of biology which will inelude copies of the classic works of the past. It is hoped that the new rooms will be found useful, possibly in different ways, by members from the Colonies spending long leaves in Britain, by the many members in the London area who have no access to similar facilities in central London and by those from other parts of Britain paying brief visits to London.

\section{Television Transmitter at Meldrum, Aberdeen- shire}

THE opening on October 12 of a new B.B.C. medium-power transmitting station at Meldrum, Aberdeenshire, brings television within the reach of about half a million people living in the north-east corner of Scotland, south of the Moray Firth. This transmitter replaces the temporary low-power transmitter at Redmoss, Aberdeen, the useful service-area of which did not extend much beyond the city boundaries. The $5 \cdot \mathrm{kW}$. vision and $1 \cdot 25 \cdot \mathrm{kW}$. sound transmitters, manufactured by Marconi's Wireless Telegraph Co., Ltd., feed a three-stack 'batwing' aerial mounted at the top of a $500-\mathrm{ft}$. steel mast. The mast and station are situated on a hilltop, so that the aerial is about $1,300 \mathrm{ft}$. above sea-level. About halfway up the mast is an eight-tier slotted aerial from which the B.B.C. Home, Light and 'Third programmes will be radiated when frequency-modulated veryhigh-frequency transmitters are installed early in 